\title{
INTERNATIONAL BUSINESS BOOKS/PUBLICATIONS RECEIVED BETWEEN OCTOBER 1, 2000, AND MARCH 31, 2001
}

The Asian Economic Catharsis: How Asian Firms Bounce Back from Crisis, FrankJürgen Richter, editor. Quorum Books, Westport, CT, 2000 (hard) $\$ 69.50$ US.

The Auditor's Talk: An Oral History of the Profession from the 1920s to the Present Day, Derek Matthews and Jim Pirie, Garland Publishing, New York, NY (2001) $\$ 120.00$ hard.

Beyond the Bottom Line: Socially Innovative Business Owners, Jack Quarter, Quorum Books, Westport, CT, 2000 (hard) $\$ 59.95$ US.

Building the Integrated Company, Malcolm A. Birkin, Gower Publishing, Burlington, VT 2000 (hard) \$84.95 US.

Complex Responsive Processes in Organizations: Learning and Knowledge Creation, Ralph D. Stacey, Routledge, New York, NY (2001) \$18.99 US paper.

Complexity and Management: Fad or Radical Challenge to Systems Thinking?, Ralph D. Stacey, Douglas Griffin, and Patricia Shaw, Routledge, New York, NY (2000) $\$ 18.99$ US paper.

Contests for Corporate Control: Corporate Governance and Economic Performance in the United States and Germany, Mary A. O'Sullivan, Oxford University Press, New York, NY 2000 (hard) $\$ 70.00$ US.

Cooperative Strategy: Economic, Business and Organizational Issues, David Faulkner and Mark De Rond, editors. Oxford University Press, New York, NY, 2000 (hard) $\$ 74.00$ US.

Corporate Governance and Globalization: Long Range Planning Issues, Stephen S. Cohen and Gavin Boyd, editors. Edward Elgar Publishing, Inc., Northampton, MA, 2000 (hard) $\$ 110.00$ US.

The East Asian Development Model: Economic Growth, Institutional Failure and the Aftermath of the Crisis. Frank-Jürgen Richter, editor. New York, NY: Palgrave Global Publishing at St. Martin’s Press, 2000 (hard) \$69.95 US.

Economics of International Business: A New Research Agenda, Mark Casson, Edward Elgar Publishing, Inc., Northampton, MA, 2000 (hard) \$100.00 US.

Economic Policy Reform: The Second Stage, Anne O. Krueger, editor. University of Chicago Press, Chicago, IL (hard) $\$ 65.00$ US.

Entrepreneurial Education: Mapping the Debates in the United States, the United Kingdom and Finland, Kristiina Erkkilä, Garland Publishing, New York, NY (2000) $\$ 65.00$ hard.

The Federal Trade Commission: A Guide to Sources, Robert V. Labaree, Garland Publishing, New York, NY (2000) \$85.00 US hard.

Foreign Direct Investment in Emerging Economies: Corporate Strategy and Investment Behaviour in the Carribean, Lou Anne A. Barclay. Routledge, New York, NY, 2000 (hard). 
From Silicon Valley to Singapore: Location and Competitive Advantage in the Hard Disk Drive Industry, David G. McKendrick, Richard F. Doner, Stephan Haggard, Stanford University Press, Stanford, CA (2000) \$22.95 US paper.

Global Strategies and Local Realities: The Auto Industry in Emerging Markets. John Humphrey, Yveline Lecler and Mario Sergio Salerno, editors. New York, NY: Palgrave Global Publishing at St. Martin's Press, 2000 (hard) \$69.95 US.

The Globalization of Business and the Middle East: Opportunities and Constraints, Masoud Kavoossi, Quorum Books, Westport, CT (hard) \$65.00 US.

Globalization of Japan: Japanese Sakoku Mentality and U.S. Efforts to Open Japan. Mayumi Itoh. New York, NY: St. Martin's Press, 2000 (soft) \$18.95 US.

How to Enter China: Choices and Lessons, Yadong Luo, University of Michigan Press, Ann Arbor, MI (2000) \$59.50 US hard.

How to Get an MBA, Morgan Witzel, Routledge, New York, NY (2000) \$16.95 US paper.

Import Propensities of Industrialized Countries: Protectionism Revealed. James M. Lutz. New York, NY: St. Martin’s Press, 2000 (hard) \$49.95 US.

International Asset Securitization and Other Financing Tools, Susan Meek, editor, Transnational Publishers, Inc., Ardsley, NY 2000 (hard) $\$ 125.00$ US.

International Deregulation and Privatization, Christian Campbell, editor, Transnational Publishers, Inc., Ardsley, NY 2000 (hard) \$125.00 US.

International Joint Ventures: Theory and Practice, Aimin Yan and Yadong Luo. M.E. Sharpe, Armonk, NY, 2001 (hard) \$89.95 US.

Investing in International Real Estate, M.A. Hines, Quorum Books, Westport, CT 2000 (hard) \$69.95 US.

Knowledge and Innovation in the New Service Economy, Birgitte Andersen, Jeremy Howells, Richard Hull, Ian Miles, Joanne Roberts, editors, Edward Elgar Publishing, Inc., Northampton, MA (2000) \$95.00 US hard.

The Limits of Convergence: Globalization and Organizational Change in Argentina, South Korea and Spain, Mauro F. Guillén, Princeton University Press, Princeton, NJ (2001) \$35.00 US hard.

Negotiating NAFTA: Explaining the Outcome in Culture, Textiles, Autos, and Pharmaceuticals, Maryse Robert, University of Toronto Press, Toronto, Canada (2000) $\$ 24.95$ US paper.

The Social Consequences of Economic Restructuring in the Textile Industry: Change in a Southern Mill Village, Cynthia D. Anderson, Garland Publishing, New York, NY (2001) $\$ 60.00$ US hard.

Strategies for Central and Eastern Europe, Andrej K. Kozminski and George S. Yip, editors, St. Martin's Press, New York, NY 2000 (hard).

A Yen for Real Estate: Japanese Real Estate Investment Abroad - From Boom to Bust, Roger Simon Farrell. Edward Elgar Publishing, Inc., Northampton, MA, 2000 (hard) $\$ 95.00$ US. 